\title{
From phraseo-didactics to higher linguistic culture
}

\author{
Andrej Habiňák \\ Department of Linguistic Communication \\ Faculty of Mass Media Communication \\ University of Ss. Cyril and Methodius in Trnava \\ Trnava, Slovakia \\ andrej.habinak@ucm.sk
}

\begin{abstract}
In the paper the author discusses the level of linguistic culture and possibilities how to improve it continually in discourses. One of the possible ways how to improve speaker's discourse is to use phraseology - phraseological units. It is known this part of vocabulary is apposite, concise and metaphorical; it enriches the discourse and presents a possibility to know also the culture and mentality of a nation speaking the particular language. Phraseologisms have been formed during centuries, they are our cultural heritage and treasure chest of a nation's culture and identity. The author of the paper offers a view on the use of phraseology at basic schools in Slovakia when teaching the mother tongue and presents the most frequently used methods and ways of dealing with phraseology in education.
\end{abstract}

Keywords-phraseology; education; linguistic culture; educational methods.

\section{INTRODUCTION}

During the last decades the professional and general public continually observe that the vocabulary and discourse of a modern man deteriorates in general refinement and grace. Why does it happen? Partially, it is a result of an over-technological world and progress connected with it along with unlimited improvements in a man's comfort. These lead to a general indifference and in case of linguistic skills to an apparent atrophy. It is primarily the result of a weak influence upon the quality of linguistic culture, the quality of linguistic discourse as such.

It is undisputable that it is the mass media who should participate in increasing the linguistic culture of a nation as they address the general public and influence a wide range of listeners and viewers. In accordance with the major opinion of the professional public we do also believe that it is primarily the school as institution that should be responsible for a thorough spreading of the standard language, refinement of the linguistic discourse and increasing the linguistic culture in all style levels and communication situations. We should emphasise the development of abilities such as: expressing one's opinions, impressions, remarks and ideas swiftly not only in the objective way but also in the emotional and suggestive ones.

On the basis of the above mentioned it is not daring to ask to inform, teach and educate a pupil about the possibility of increasing the efficiency of verbal discourse that has been present in literature and current speech for centuries, our mother tongue including. We suppose s school should be the first one to teach these communicative and expressive skills. Such a school should prepare its pupils for a more accurate and truthful composition of one's language. However, the role of a family background cannot be neglected.

One of the possible solutions of solving the question of improving linguistic discourse does not have o be searched for in a distant future. On the contrary, we could make use of the past, the history. The elderly generation of our population could be the example, model to us. Their discourse is full of figurative, symbolical, allegorical and metaphorical phrases, words and sentence constructions. They are specific for their diversity, richness and wisdom reflecting long-time experience of the preceding generations, their wisdom and intelligence. We call them phraseologisms/idioms.

This idea should not be presented as our amazing discovery, quite the other way. Since certain time we deal with phraseologisms more and more often in school practice (we mainly think of teaching texts, their practical use depends on a teacher himself).

Nowadays, there are researches going on in Europe and Slovakia as well. They aim at implementation of empirical researches in the field of phrase-literacy and their goal is to propose methods for removal of found deficiencies on the basis of acquired knowledge and to support proven methods used in phrase-didactics.

\section{METHODOLOGY IN PHRASEOLOGY}

The methodology of teaching phraseology at basic and secondary schools emphasises the mastering of the phraseological part of a standard language in the discourse culture of pupils and its perspective usage in adulthood. This is called phraseo-didactics. By creating a methodologically suitably organized teaching process we expect the formation of so called phraseological reserve for discourse culture in the following personal development of a pupil. We should consider two aspects: the objective one, i.e. a cultivated description and learning and the subjective one, i.e. emotional, engaged and operative evaluation [1]. Should be phraseology included into the educational process at basic schools? Should we teach phraseology or why should it be not forgotten? In discussions with teachers we often hear there is a huge span of teaching material they have to deal with and therefore, the situation should not be made even more complicated by including phraseology. When we asked teachers whether they knew what Miko's or phraseological three-minute was, there was not a single person who knew (total of 64 teachers). Logically, the problem should not be formulated as whether to teach phraseology but more how to teach it. I believe all of us would agree with Miko's statement that by reinforcement of teaching 
the phraseological part in teaching standard language we improve the discourse culture of our pupils [2]. The perspective of complex communicative competencies will be demonstrated mainly in adulthood, life practice and occupation.

The importance of phraseology lies in the fact that the phraseological units:

- Develop the knowledge, creative thinking, linguistic sensitivity, because knowing, comparing and analyzing them lead pupils to a sensitive and refined selection of linguistic means in stylistics.

- Help to shape cultivated readers.

- They are source of educational effects as by their usage we influence the emotional attitude to language, to folk wisdom and ethics of behaviour (wittily, poetically or expressively, but always with ethical context do they record folk and man's wisdom and life experience of several generations and ages).

Several statements of our linguists agree with those we can find in the publication of the English pedagogue A. Hughes et al. titled Testing for Language Teachers. Besides other interesting facts he introduces a scale that evaluates the quality of mastering and using a language in six qualitative levels. The highest level (the sixth one) of mastering a foreign language is represented by a group of users who "...use vocabulary and idioms rarely (if at all) recognisable distinguishable from that of educated native writer"[3]. By stating it did the author emphasise that having the knowledge about idioms (as we know more popular term in some countries for phraseologisms) means having a higher level of knowing and mastering a particular language. This scheme can be thus applied to a mother tongue and the level of knowledge a nation has about its own language. Another important remark - members of Hughes' sixth level know and can adequately use idioms Hughes compares them to educated native speakers/users.

We see that even the English pedagogues and linguists (i.e. those who belong to the establishing Western group of the phraseological theory since $\mathrm{Ch}$. Bally) agree with the opinion of prof. Mlacek who stated in the 70's of the last century:"Phraseology is generally considered as one of the most general areas in every natural language and depending on the level of its mastering we can assess the overall level of knowing the mother tongue and foreign language" [4].

We think that besides other statements also this fact is a reliable base for reasoning the teaching of phraseology at basic schools and acquiring this relatively independent part of lexicology for our everyday and professional needs.

\section{TEACHING PHRASEOLOGY}

Phraseological units are naming or expressive units into which an author can include his attitude to reality (they allow a more precise and complex depiction of reality), his sense of humour, wit, joke, actual mood, temperament and other moments he wants to express in subtext to achieve a more lively, attractive and expressive communication process. Without idioms a discourse is tedious. Phraseological units are intensifying factors of communication and an abundant source of metaphorical, effective, concise and comprehensible language.

Based on the main goal of teaching Slovak language and literature, which is setting the basis for communication skills of pupils, it is necessary and required to include suitable phraseological units into linguistic material because they are an organic part of a real language. Teaching Slovak language at the second grade of basic school is focused on developing communication competence of pupils in common real-life situations. Due to this fact we agree with J. Svobodová [5] who states that accepting the idea that one meaning can be expressed by several words (phraseological term) should be started with pupils of the first grade at basic schools and developed further at the second grade.

Prof. Miko is regarded as a pioneer in the Slovak phrasedidactics. He is the author of Phraseology at school, first phrase-didactic guide ever. At present, it is prof. Durčo who intensively deals with this issue. He has broadened the research field and focuses on teaching phraseology of foreign languages. The importance of phraseology in education is not limited my mother tongue only. We come into contact with phrasal idioms, collocations, phrases (as petrified phrases) in teaching foreign language as well. We learn not only the meaning of those, but also the culture and mentality of a nation speaking the language. Habiňáková stresses that “... language and culture are mutually inseparable. When learning foreign language a student acquires not only the phonological, grammatical and semantic level of the language. He broadens his horizons of personal and social values and enriches them with new knowledge" [6].

Miko was the first one to point out the deficiencies in teaching phraseology in Slovak schools, poor presence of phraseologisms in course books and their absence in curricula. Not only did he emphasise the deficiencies in teaching, he also proposed specific agenda for teachers allowing them to include unobtrusively this specific topic into the classes of Slovak language. Probably the best known is his time-saving and pragmatic proposal called a phraseological three-minute. Miko's phraseological three-minute consists of three parts:

a) Presenting the phrase (with its possible variants).

b) Its interpretation.

c) Listing synonymous and antonymous phrases. We comment on these phrases when necessary [2].

Valuable methodological stimuli for phraseology have been provided by prof. Durčo, mainly his model approach to defining the meaning of idioms and specification of semasiological and onomasiological models. The author further divides both types and illustrates those using examples. He highlights the functional-semantic model of idioms by F. Miko [7]. Several professionals (e.g. Durčo, Pekarovičová and others) deal with the design of methodology for selection and form of presenting phraseological units considering the development of receptive and productive skills in order to make the process of acquiring communicatively relevant idioms more effective. It is important to mention also the call of numerous phraseologists and phraseomethodologists to define the phrase-communicative minimum. 
Miko suggests the use of several other methods when working with phraseological units within the integrated parts of the Slovak language courses:'Besides phraseological threeminutes a teacher can work with texts during the courses on composition or literary education along with other forms. Depending on the topic of a composition recommended phrases could be highlighted. During courses where pupils read literary texts, they can look for phraseologisms in texts, interpret them and look for synonymous and antonymous equivalents [2].

There is not much negative we could say about current teaching materials. Since Miko negatively assessed didactic aids [2] there has been a significant progress in the quantity and quality of phraseological units found in textbooks. We are satisfied with such a state, even though the quality and variety does not necessarily mean a qualitative progress in knowledge.

However, many schools still lack workbooks, methodological guides, dictionaries of phraseology and magazines [7]. On the other hand we see improvements in introducing IT to schools. This allows not only a better access to the theoretical knowledge but also makes the use of audiovisual technology and the electronic phraseology textbook such as EPHRAS possible [8].

The importance of phraseology and specifically knowledge about culture and understanding the culturally determined aspects is emphasized also in the works of Petranová [9] and Pravdová [10] and many other authors. Understanding a message (even mediated via mass media and between various cultures) is crucial for achieving the intercultural understanding.

Phraseology can also be the treasure box of historic artefacts and documents on life and organization of a society in several subsequent generations. In phraseology various characteristic features typical for a particular period of their origin are demonstrated. The topic is also discussed by $\mathrm{M}$. Solík [12]. When proposing didactic concepts in phraseology we have to take into consideration the knowledge and results of the researches on development psychology. The level of cognitive development can be seen not only in the ability of critical thinking but also in the ability to verbalize one's emotions and ideas, relate and compare individual pieces of information and assign them their meaning. Critical competencies are analyzed in the work of D. Petranová [11].

\section{REFERENCES}

[1] J. Mlacek, P. Ďurčo, et al., "Frazeologická terminológia," Bratislava: Stimul, 1995.

[2] F. Miko, et al., "Frazeológia v škole," Bratislava: Slovenské pedagogické nakladatel'stvo, pp. 11-64, 1989.

[3] A. Hughes, "Testing for Language Teachers," Cambridge: Press Syndicate of the University of Cambridge, p. 170, 1989.

[4] J. Mlacek, "Slovenská frazeológia," Bratislava: Slovenské pedagogické nakladatel'stvo, 1984.

[5] J. Svobodová, "Jazyková specifika školské komunikace a výuka mateřštiny," in Spisy Ostravské univerzity. Ostrava: Ostravská univerzita, p. 126, 2000.

[6] E. Habiňáková, "Kultúrne obsahy v kontexte interkultúrnej komunikácie," Trnava: Univerzita sv. Cyrila a Metoda v Trnave, p. 5, 2013.

[7] E. Habiňáková, “ Integrácia kultúrneho obsahu ako ciel’ výučby cudzieho jazyka”. In: Jazykovedné, literárnovedné a didaktické kolokvium XX. = Linguistic, Literary and Didactic Colloqium XX., nonconference reviewed collection of papers, Bratislava : Z-F LINGUA, 2013, p.145-152.

[8] P. Durčo, "Metodologické problémy všeobecnej frazeológie," in Frazeologické štúdie I. Bratislava: STIMUL, pp. 91-113, 1996.

[9] D. Petranová, "The Media Literacy Level Of Slovak Seniors," Communication Today, vol. 5, no. 1, pp. 71-85, 2014.

[10] H. Pravdová, "Fenomén zábavy a úloha stereotypov v produkcii a recepcii mediálnej kultúry, "Communication Today, vol 2/ issue 1, pp. 7 $-24,2011$.

[11] D. Petranová, "Rozvíja mediálna výchova v školách kritické kompetencie žiakov?,“ Communication Today, vol 2/ issue 1, p. 78, 2011.

[12] M. Solík, "Komunikácia v spoločenskom kontexte - uznanie ako intersubjektívny predpoklad,“"Communication Today, vol 1/issue 2 , pp. 41- 57, 2010. 